\title{
Acute toxicity of benzalkonium chloride in Balb/c mice following intratracheal instillation and oral administration
}

\author{
Handule Lee, Kwangsik Park (D) \\ College of Pharmacy, Dongduk Women's University, Seoul 02748, Korea
}

Benzalkonium chloride is a cationic surfactant widely used as a disinfectant, preservative, and sanitizer in many public places as well as domestically. The purpose of this study is to compare the acute toxicity of lethal doses $\left(L_{x}\right)$ and the target organs after intratracheal instillation and oral ingestion by mice, which is a preliminary test prior to the repeated dose toxicity test. When Balb/c mice were treated with a single dose of benzalkonium chloride via oral administration, $L_{50}$ was $241.7 \mathrm{mg} / \mathrm{kg}$. However, it was comparatively decreased to $8.5 \mathrm{mg} / \mathrm{kg}$ following intratracheal treatment, which suggests that lung may be the main target of toxicity. Although the histopathology showed inflammatory responses in the lung after intratracheal instillation, it still did not confirm that the inflammatory responses were the key factors inducing death in the treated animal. Acute and fatal mechanisms such as bronchoconstriction or neurotoxicity associated with benzalkonium chloride exposure should be further investigated.

Keywords: benzalkonium chloride, acute toxicity, lethal dose, Balb/c mice, intratracheal instillation

\section{INTRODUCTION}

Quaternary ammonium compounds (QACs) are a group of cationic substances that are widely used in industrial and household products including disinfectants, preservatives, and detergents. Benzalkonium chloride (BAC) is one of the most frequently used QACs known to cause toxic effects on the skin, eyes, and the airways [1,2]. A few medicines contain low concentrations of BAC $(0.007-0.01 \%)$ as preservative or stabilizers while many disinfectants often contain higher concentrations of BAC $(0.01-80 \%)$. Some disinfectants are readily usable (0.01-0.2\%), but most products are usually commercially available as $10 \%$ BAC for use after dilution. In Japan, products for hospital use contain up to $50 \%$ to $80 \%$ BAC [3]. Therefore, accidental or suicidal ingestion of BAC may frequently result in serious poisoning. Unintended inhalation of the chemical in closed cleaning rooms or other places has been reported in many countries, including a number of reports of accidental exposure to BAC, resulting in death or a se-

Received: June 18, 2019 Accepted: Aug 12, 2019

Corresponding author: Kwangsik Park

60, Hwarang-ro, 13-gil, Seongbuk-gu, Seoul 02748, Korea

Tel: +82-2-940-4522, Fax: +82-2-940-4195

E-mail:kspark@dongduk.ac.kr

This article is available from: http://eaht.org rious injury [4-6]. A previous study demonstrated that BAC may increase the immune response in mice, which may increase the risk of allergy. Inhalation of higher concentrations of BAC induced intense pulmonary effects and inflammation. However, it may not be the cause of death because inflammatory response was not fatal in those studies $[7,8]$.

The purpose of this study is to compare the acute toxicity of lethal doses(LDx) after intratracheal instillation and oral administration of BAC to Balb/c mice, prior to testing for toxicity to repeated dose exposure. Histological analysis of lung and liver was also performed to determine the fatal effects of damage to the target organs.

\section{METHODS}

BAC was purchased from Sigma-Aldrich (Cat No; 12060100G, St. Louis, MO, USA). Six-week-old male Balb/c mice were obtained from Young-Bio (Gyunggi-do, Korea) and acclimatized to laboratory conditions for one week before the initiation of the experiment. The average body weight of the animal before BAC treatment was about $20 \pm 2 \mathrm{~g}$. Diet and water were provided ad libitum. The animal facility was maintained at $23 \pm 3^{\circ} \mathrm{C}$ with a $12 \mathrm{~h}$ light/dark cycle (light on from 8:00 to 20:00 h). Six mice were held in a cage and treated with BAC via intratracheal instillation or oral administration. BAC was solu- 
bilized in saline and treated with doses of 1.25, 2.5, 5, 10, 20, and $30 \mathrm{mg} / \mathrm{kg}$. A total of $0.2 \mathrm{~mL}$ was instilled in each mouse, and a similar volume of saline without BAC was used to treat each animal in the control group. For oral administration of BAC, mice were fasted overnight before the experiment. Each of the six mice was treated with doses of 100, 150, 200, 300, and $400 \mathrm{mg} / \mathrm{kg}$. After treatment with BAC, mice were monitored for 14 days. All the animals used in this study were treated in accordance with "Guidance for the Care and Use of Laboratory Animals" and approved by the Committee of Dongduk Women's University (Approval No; 20181113).

Dead or moribund mice were immediately removed from the cages, followed by post-mortem inspection. Small portions of tissue samples were harvested after death. Tissues were fixed in $10 \%$ phosphate buffered formalin via immersion, and embedded in paraffin, sectioned, stained with hematoxylin and eosin (H\&E), and examined microscopically. Hitopathological analysis was performed as test project of "19-MO0336N" in Chemon Inc (Suwon, Korea). For each mouse, the observation was made over a period of 14 days, and the toxicity symptoms and mortality rate in each group were noted.
Dead animals were counted every $24 \mathrm{~h}$. The $\mathrm{LD}_{50}$ was calculated using the arithmetic method of Karber $[9,10]$.

$L D_{50}=L D_{100}-\sum(a \times b) / n$

where $n$ is the total number of animals in a group,

$a$ is the difference between two successive doses of administered extract/substance,

$b$ is the average number of dead animals in two successive doses, and

$L D_{100}$ is the lethal dose causing $100 \%$ death of all the test animals.

\section{RESULTS}

\section{$50 \%$ lethal dose $\left(\mathrm{LD}_{50}\right)$}

A few mice exposed to BAC treatment were dead immediately after the treatment. The number of dead animals was increased by the increased dose and duration. As shown in Table 1 , all the mice were dead after the oral administration of BAC $400 \mathrm{mg} / \mathrm{kg}$ within $24 \mathrm{~h}$ and none was harmed by exposure to $100 \mathrm{mg} / \mathrm{kg}$ by day 14 , the end of the experiment. At the dose of 150-300 mg/kg, dose-dependent mortality was observed and the number of dead mice was increased with time.

Table 1. Acute toxicity of benzalkonium chloride in mice after treatment via oral administration or intratracheal instillation

\begin{tabular}{|c|c|c|c|c|c|c|c|c|c|}
\hline \multirow{2}{*}{ Route } & \multirow{2}{*}{ Dose (mg/kg) } & \multicolumn{8}{|c|}{ Exposed duration (d) } \\
\hline & & 1 & 2 & 3 & 4 & 5 & 6 & 7 & 14 \\
\hline \multirow[t]{6}{*}{ Oral administration } & 400 & 6 & 6 & 6 & 6 & 6 & 6 & 6 & 6 \\
\hline & 300 & 5 & 5 & 5 & 6 & 6 & 6 & 6 & 6 \\
\hline & 200 & 2 & 4 & 4 & 4 & 4 & 4 & 4 & 4 \\
\hline & 150 & 0 & 0 & 2 & 3 & 3 & 3 & 3 & 3 \\
\hline & 100 & 0 & 0 & 0 & 0 & 0 & 0 & 0 & 0 \\
\hline & 0 & 0 & 0 & 0 & 0 & 0 & 0 & 0 & 0 \\
\hline \multirow[t]{7}{*}{ Intratracheal instillation } & 30 & 6 & 6 & 6 & 6 & 6 & 6 & 6 & 6 \\
\hline & 20 & 5 & 5 & 5 & 5 & 5 & 5 & 5 & 5 \\
\hline & 10 & 4 & 4 & 4 & 4 & 4 & 4 & 4 & 4 \\
\hline & 5 & 4 & 4 & 4 & 4 & 4 & 4 & 4 & 4 \\
\hline & 2.5 & 2 & 2 & 2 & 2 & 2 & 2 & 2 & 2 \\
\hline & 1.25 & 0 & 0 & 0 & 0 & 0 & 0 & 0 & 0 \\
\hline & 0 & 0 & 0 & 0 & 0 & 0 & 0 & 0 & 0 \\
\hline
\end{tabular}

The accumulated number of dead mice were represented after treatment of benzalkonium chloride at the designated observation period. Total 6 mice were held in a group and treated with benzalkonium chloride.

Table 2. Parameters for calculation of $50 \%$ lethal dose $\left(L D_{50}\right)$ using the arithmetic methods of Karber

\begin{tabular}{|c|c|c|c|c|c|c|}
\hline & Dose (mg/kg) & $\begin{array}{l}\text { Dose difference } \\
(\mathrm{mg} / \mathrm{kg})(\mathrm{a})\end{array}$ & Number of dead mice & Mean (b) & Product $(a * b)$ & $\mathrm{LD}_{50}(\mathrm{mg} / \mathrm{kg})$ \\
\hline \multirow[t]{5}{*}{ Oral administration } & 400 & - & 6 & - & - & \multirow{5}{*}{241.7} \\
\hline & 300 & 100 & 5 & 5.5 & 550 & \\
\hline & 200 & 100 & 2 & 3.5 & 350 & \\
\hline & 150 & 50 & 0 & 1 & 50 & \\
\hline & 100 & 50 & 0 & 0 & 0 & \\
\hline \multirow[t]{6}{*}{ Intratracheal instillation } & 30 & - & 6 & - & - & \multirow{6}{*}{8.5} \\
\hline & 20 & 10 & 5 & 5.5 & 55 & \\
\hline & 10 & 10 & 4 & 4.5 & 45 & \\
\hline & 5 & 5 & 4 & 4 & 20 & \\
\hline & 2.5 & 2.5 & 2 & 3 & 7.5 & \\
\hline & 1.25 & 1.25 & 0 & 1 & 1.25 & \\
\hline
\end{tabular}


In case of intratracheal instillation of BAC, the lethality was significantly increased. When mice were treated with $30 \mathrm{mg} /$ $\mathrm{kg}$, all the mice were killed soon after the treatment as shown in Table 1. Five of the six mice were dead within $24 \mathrm{~h}$ upon treatment with $20 \mathrm{mg} / \mathrm{kg}$ while none of them died following exposure to a dose of $1.25 \mathrm{mg} / \mathrm{kg}$ during the 14 days of experiment. The mice that were not dead within $24 \mathrm{~h}$ were alive until the end of experiment. Table 2 showed the calculated parameters for the determination of $\mathrm{LD}_{50}$ used in Karber method. The $\mathrm{LD}_{50}$ of $\mathrm{BAC}$ in the orally administered group at $24 \mathrm{~h}$ posttreatment was $241.7 \mathrm{mg} / \mathrm{kg}$ while the $\mathrm{LD}_{50}$ in intratracheally instilled group at the same time was $8.5 \mathrm{mg} / \mathrm{kg}$, which was significantly low compared with oral administration.

\section{Histopathological examination}

Histopathological examination of the liver in the mouse treated with BAC orally and via intratracheal instillation did not show any specific lesions. Furthermore, no lung damage was detected when mice were treated via oral administration. However, BAC-related tissue damage was observed in lung tissue of mice treated with intratracheal instillation. Congestion and hemorrhage (diffused), acute alveolar wall injury, and intravascular fibrin thrombus were observed in all the BACtreated mice $(20 \mathrm{mg} / \mathrm{kg})$. The summary of findings involving tissue damage is presented in Table 3. Representative histological findings of lungs from mice treated via intratracheal instillation are shown in Fig.1. Diffuse congestion and hemorrhage, necrotizing alveolar wall and thrombus formation in small vessels and terminal bronchioles are shown.

\section{DISCUSSION}

BAC is widely used as an active ingredient in household and personal care products in Korea. The products are easily available and many cases of accidental poisoning may have been reported. According to the toxicity data available, BAC may
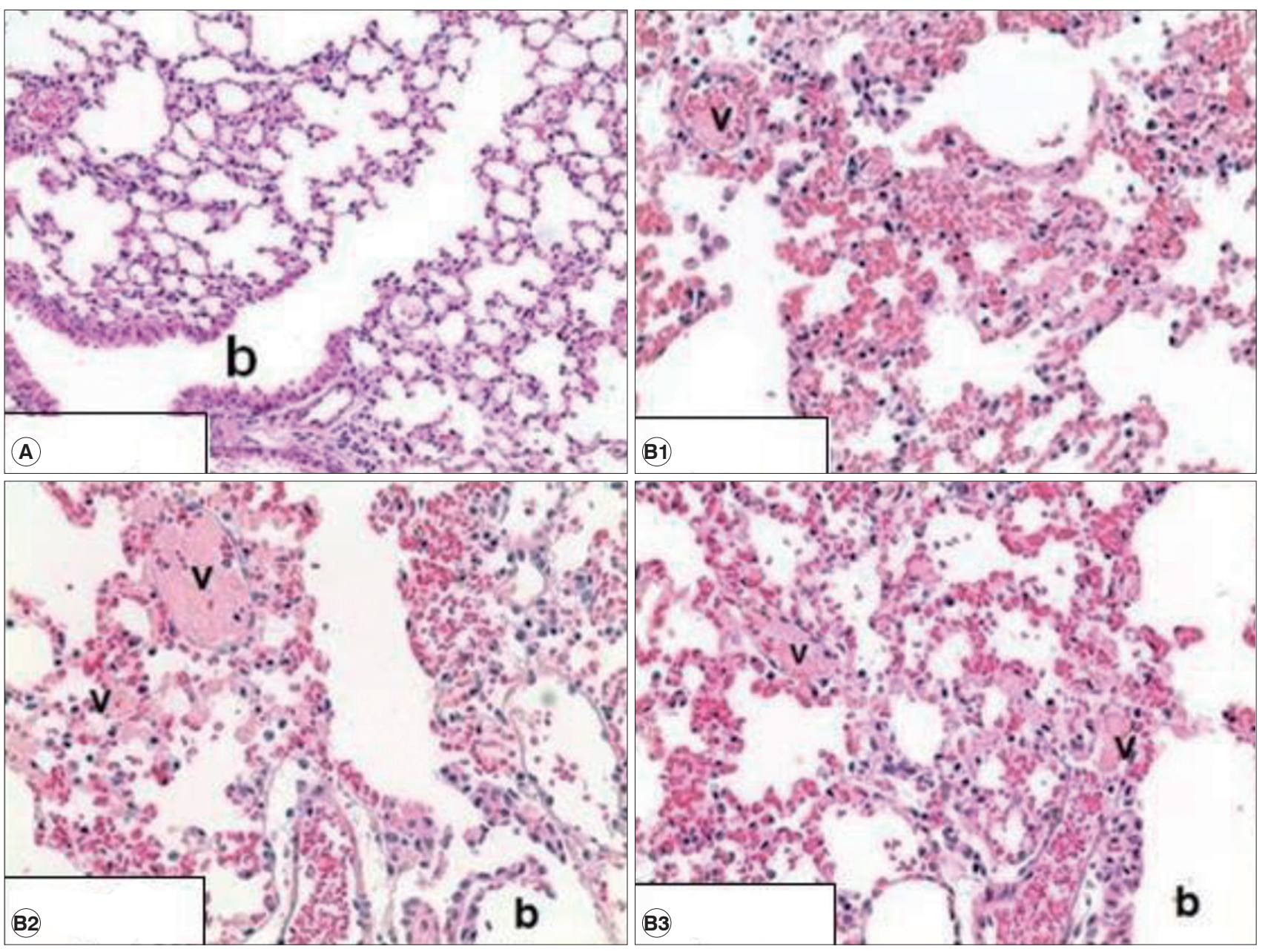

Figure 1. Histological findings in the lungs of control group (A) and treated group (B) with $20 \mathrm{mg} / \mathrm{kg}$ via intratracheal instillation. In treated group, diffuse congestion and hemorrhage, necrotizing alveolar wall and fibrin thrombus in small vessels were observed while no lesion were found in control group. Image $A$ represents for control group $(x 200, n=3)$ and those of $B$ represent three respective mice $(x 400, n=3)$. b: terminal bronchiole. v: small vessels. 
Table 3. Summary of the histopathological findings in mice after treatment of benzalkonium chloride

\begin{tabular}{lccc}
\hline Organ and histopathological findings & Control & $\begin{array}{c}\text { Intratracheal } \\
(20 \mathrm{mg} / \mathrm{kg})\end{array}$ & $\begin{array}{c}\text { Oral } \\
(200 \mathrm{mg} / \mathrm{kg})\end{array}$ \\
\hline Liver & 2 & 3 & 3 \\
No specific lesion & 1 & 3 & 3 \\
Mononuclear cell foci & 1 & 0 & 0 \\
Grades: minimal & 1 & 0 & 0 \\
Lung & 2 & 3 & 3 \\
No specific lesion & 2 & 0 & 2 \\
Congestion \& Hemorrhage, diffuse & 0 & 3 & 0 \\
Alveolar wall injury, acute & 0 & 3 & 0 \\
Fibrin thrombus, intravascular & 0 & 3 & $1^{*}$ \\
\hline
\end{tabular}

The number of mice that have histopathological findings were counted. Bold number represents for the total examined mice. *; focal.

cause adverse effects on eye, skin, and respiratory system [1113]. However, acute toxicity of BAC, especially inhaled toxicity involving cases of poisoning, has not been adequately reported. The $\mathrm{LD}_{50}$ of $\mathrm{BAC}$ in rats was $234-525 \mathrm{mg} / \mathrm{kg}$ and $14 \mathrm{mg} / \mathrm{kg}$ when administered orally and intravenously, respectively [2]. In humans, an oral dose of $100-400 \mathrm{mg} / \mathrm{kg}$ or a parenteral dose of $5-15 \mathrm{mg} / \mathrm{kg}$ is thought result in fatal outcomes [3,5]. However, the fatal dose of inhalation or lung burden in case of accidental acute poisoning is unknown.

In this study, the acute toxicity test was performed and the $\mathrm{LD}_{50}$ of intratracheal instillation in Balb/c mice was calculated and compared with that of oral administration. The $\mathrm{LD}_{50}$ at 24 $\mathrm{h}$ after intratracheal instillation was $8.5 \mathrm{mg} / \mathrm{kg}$, which was significantly low compared with $241.7 \mathrm{mg} / \mathrm{kg}$ via oral administration. The $\mathrm{LD}_{50}$ of oral administration was in the range reported those obtained from rats [2,3].

Histological examination revealed no liver damage in mice after oral administration as well as intratracheal instillation. Intratracheal instillation revealed lung damage; however, no any other pathological findings involving liver were detected. The histological findings involving lung, including diffuse congestion and hemorrhage, necrotizing alveolar wall and fibrin thrombus in small vessels may not be serious nor fatal to the mice, as shown in Table 3 and Fig.1. The direct cause of death in mice treated with acute high dosage of BAC could not be determined easily. It was reported that BAC induced bronchoconstriction in patients with stable bronchial asthma [13]. Thus, serious bronchoconstriction may be one of the major factors inducing death in mice immediately post-treatment. Although inflammatory response and oxidative stress were known to be induced by BAC $[14,15]$, they were not associated with fatal outcomes. Effects of BAC on bronchoconstriction will be further investigated considering the possibility of neurotoxicity, which may interfere with respiration or cardiac function.

\section{ACKNOWLEDGMENTS}

This work was supported by the Dongduk Women's University grant.

\section{CONFLICT OF INTEREST}

The authors have no conflict of interests to report.

\section{REFERENCES}

1. Larsen ST, Verder H, Nielsen GD. Airway effects of inhaled quaternary ammonium compounds in mice. Basic Clin Pharmacol Toxicol 2012; 110(6):537-543.

2. Xue Y, Zhang S, Tang M, Zhang T, Wang Y, Hieda Y, et al. Comparative study on toxic effects induced by oral or intravascular administration of commonly used disinfectants and surfactants in rats. J Appl Toxicol 2012; 32(7):480-487.

3. Xue Y, Hieda Y, Saito Y, Nomura T, Fujihara J, Takayama K, et al. Distribution and disposition of benzalkonium chloride following various routes of administration in rats. Toxicol Lett 2004; 148(1-2):113-123.

4. Hitosugi M, Maruyama K, Takatsu A. A case of fatal benzalkonium chloride poisoning. Int J Legal Med 1998;111(5):265-266.

5. Wilson JT, Burr IM. Benzalkonium chloride poisoning in infant twins. Am J Dis Child 1975; 129(10):1208-1209.

6. Akutsu I, Motojima S, Ogata H, Fukuda T, Ikemori R, Makino S. A case of acute benzalkonium chloride intoxication. Nihon Naika Gakkai Zasshi 1989;78(11):1613-1614. [Article in Japanese]

7. Johnson NF. Pulmonary Toxicity of Benzalkonium Chloride. J Aerosol Med Pulm Drug Deliv 2018; 31(1):1-17.

8. Swiercz R, Hałatek T, Stetkiewicz J, Wąsowicz W, Kur B, Grzelińska Z, et al. Toxic effect in the lungs of rats after inhalation exposure to benzalkonium chloride. Int J Occup Med Environ Health 2013;26(4):647-656.

9. Ahmed M. Acute toxicity (lethal dose 50 calculation) of herbal drug Somina in rats and mice. Pharmacol Pharm 2015;6(3):185-189.

10. Karber, G. Beitrag zur kollecktiven Behandlung pharmakologischer Reihenversuche. Arch Exptl Pathol Pharmakol 1931;162(4):480-483. [Article in German]

11. Basketter DA, Marriott M, Gilmour NJ, White IR. Strong irritants masquerading as skin allergens: the case of benzalkonium chloride. Contact Dermatitis 2004;50(4):213-217.

12. Cha SH, Lee JS, Oum BS, Kim CD. Corneal epithelial cellular dysfunction from benzalkonium chloride (BAC) in vitro. Clin Exp Ophthalmol 2004;32(2):180-184.

13. Lee BH, Kim SH. Benzalkonium chloride induced bronchoconstriction in patients with stable bronchial asthma. Korean J Intern Med 2007;22(4):244-252.

14. Jeon H, Kim D, Yoo J, Kwon S. Effects of benzalkonium chloride on cell viability, inflammatory response, and oxidative stress of human alveolar epithelial cells cultured in a dynamic culture condition. Toxicol In Vitro 2019;59:221-227.

15. Kwon D, Lim YM, Kwon JT, Shim I, Kim E, Lee DH, et al. Evaluation of pulmonary toxicity of benzalkonium chloride and triethylene glycol mixtures using in vitro and in vivo systems. Environ Toxicol 2019;34(5):561-572. 